\title{
Comparative Adoption Level of Improved Animal Husbandry Practices by Dairy Farmers of Kheda and Panchmahal Districts of Middle Gujarat, India
}

\author{
B.S. Divekar* and M.M. Trivedi \\ Livestock Research Station, College of Veterinary Science and Animal Husbandry, \\ Anand Agricultural University, Anand-388110, Gujarat, India \\ *Corresponding author
}

A B S T R A C T

\begin{tabular}{|l|}
\hline Ke y w o r d s \\
$\begin{array}{l}\text { Dairy farmers of } \\
\text { Gujarat, Adoption } \\
\text { level, Breeding } \\
\text { practices, Milking } \\
\text { practices, Feeding } \\
\text { practices, Calf rearing } \\
\text { practices. }\end{array}$ \\
\hline Article Info \\
\hline $\begin{array}{l}\text { Accepted: } \\
\text { 24 September } 2017 \\
\text { Available Online: } \\
\text { 10 November } 2017\end{array}$ \\
\hline
\end{tabular}

The study was conducted in Kheda and Panchmahal districts of middle Gujarat during 2015-16 to assess the comparative adoption level of improved animal husbandry practices by dairy farmers of Kheda and Panchmahal districts of Gujarat. Four talukas from each district, five villages from each taluka and five respondents/dairy farmers from each village were randomly selected, thus covering 40 villages and a total of 200 respondents. The study indicated that in Kheda district most of the dairy farmers $(65.00 \%)$ possessed medium level of adoption followed by high (18.00\%) and low (17.00\%), whereas in Panchmahal district, more than half $(58.00 \%)$ of the dairy farmers had medium level of adoption followed by $21.00 \%$ each in high and low levels of adoption. The overall adoption level with regard to improved animal husbandry practices in Kheda district respondents was to the extent of $62.78 \%$ as compared to $52.83 \%$ in case of Panchmahal district. Correlation coefficient of dairy farmers' antecedent variables and their adoption level about improved animal husbandry practices indicated that variables like education, social participation, land holding, annual income, herd size and mass media exposure of Kheda district dairy farmers and annual income, herd size, risk orientation, scientific orientation and extension contact of Panchmahal district dairy farmers established positive and significant correlation with adoption level of improved animal husbandry practices.

\section{Introduction}

India ranks first in the world with annual milk production of 155.5 million tones. Most of the milk is produced from the animals reared by small and marginal farmers and landless laborers. The average per capita availability of milk is 337 grams in India and 545 grams in Gujarat (TOI, 2016). During $11^{\text {th }}$ five year plan (2007-08 to 2011-12), the average annual growth rate of milk production in India was $4.5 \%$. Gujarat shared $7.78 \%$ of India's total milk production with a production of 10.3 million tones and holds $4^{\text {th }}$ position in the country. Milk production in Gujarat during 2012-13 has increased by 5\% than during 2011-12 (Anonymous 2014). Despite India's first rank in world milk production, the average productivity of crossbred cattle, indigenous cattle and buffaloes is 6.87, 2.14 and $4.57 \mathrm{~kg}$ of milk per day per animal, respectively. This is much lower as compared to the developed countries. The probable reasons for lower productivity are poor germplasm for milk production, inadequate feed and fodder resources as well as 
inadequate healthcare facilities. Moreover, reasons like poor adoption and diffusion of new/ improved animal husbandry technologies/practices and poor knowledge level of the dairy farmers were found responsible for lower production than the actual potential (Chander et al., 2010). The objective of the present study was to compare the adoption level of improved animal husbandry practices by dairy farmers of Kheda and Panchmahal districts of middle Gujarat.

\section{Materials and Methods}

The study was conducted in Kheda and Panchmahal districts of middle Gujarat. Kheda and Panchmahal districts were selected purposively for the study, because AMUL and Panchamrut Dairies are co-operative milk unions functioning in Kheda and Panchmahal districts, respectively. Animal husbandry is the very important economic activity of rural area in these districts. Both these districts are under the jurisdiction area of Anand Agricultural University, Anand and in recent past, both the districts were bifurcated to form two new districts, viz., Anand (from Kheda) and Dahod (from Panchmahal).

Four talukas from each district and five villages from each taluka were randomly selected. Thus, total forty villages were included in the study. From each village, five respondents/dairy farmers were randomly selected, thus making a total of 200 respondents/dairy farmers for this investigation. The impact was assessed by comparing the response of Kheda and Panchmahal districts dairy farmers towards adoption level of improved animal husbandry practices, viz., calf rearing, feeding, breeding, milking, healthcare and general management. The selected respondents were interviewed with the help of pre-tested structured interview schedule designed for this purpose.
The data thus collected were statistically analyzed to correlate respondents' profile with improved animal husbandry practices in two districts.

\section{Results and Discussion}

The comparative adoption level of dairy farmers between two districts covered under study and the results so obtained are presented in Table 1. The data clearly revealed that majority of the respondents in both Kheda $(65.00 \%)$ and Panchmahal $(58.00 \%)$ districts had medium level of adoption. The present findings are in agreement with the earlier studies (Hamdani 2008, Rizwan et al., 2015). Dairy farmers with low (17 and $21 \%$ ) and high $(18 \& 21 \%)$ levels of adoption were nearly same in both the districts. Average adoption index was $65.10 \pm 1.89$ in Kheda district and 54.72 \pm 1.59 in Panchmahal district. The higher adoption index observed in respondents of the Kheda district might be attributed to their higher knowledge index as compared to their counter part of Panchmahal. Overall adoption index observed was 59.91 \pm 1.20 . The data implied that still farmers of Panchmahal district were not adopting $45.00 \%$ of improved animal husbandry practices, and the corresponding value for Kheda district was $35.00 \%$.

The component-wise adoption level of improved animal husbandry practices by the respondents (Table 2) showed that reproductive $(73.30 \%)$, healthcare $(72.25 \%)$ and feeding $(69.90 \%)$ management practices were adopted by majority of the respondents. However, less numbers of farmers adopted milking management $(36.50 \%)$ and general management $(34.17 \%)$ practices. Prajapati (2011) reported comparable adoption rate for calf management practices. Similarly Rizwan et al., (2015) found parallel adoption rate to that of present study in breeding management practices. Moreover, adoption was higher in 
Kheda district $(62.78 \%)$ than the Panchmahal district $(52.83 \%)$ in all the improved animal husbandry practices. Overall $57.80 \%$ of the respondents adopted improved animal husbandry practices. The correlation coefficients of dairy farmers' antecedent variables and their adoption level about improved animal husbandry practices (Table 3) indicated that in Kheda district the education, land holding, annual income and herd size had positive and highly significant $(\mathrm{p}<0.01)$ association, whereas social participation and mass media exposure had positive and significant $(\mathrm{p}<0.05)$ association with adoption of improved animal husbandry practices. Further, family size and experience in dairy farming had negative and highly significant $\quad(p<0.01)$ correlation, whereas attitude towards dairy farming had negative and significant $(\mathrm{p}<0.05)$ association with adoption of improved animal husbandry practices.

Table.1 Levels of the adoption index of improved animal husbandry practices

by the dairy farmers in the study area

\begin{tabular}{|c|c|c|c|}
\hline $\begin{array}{l}\text { Sr. } \\
\text { No. }\end{array}$ & $\begin{array}{l}\text { Adoption index of improved animal } \\
\text { husbandry practices }\end{array}$ & $\mathrm{N}$ & Percentage \\
\hline \multicolumn{4}{|c|}{ Kheda district $($ Mean $=65.10, \mathrm{SD}=18.88)$} \\
\hline 1 & Low $(<48.53)$ & 17 & 17.00 \\
\hline 2 & Medium (48.54 to 81.67$)$ & 65 & 65.00 \\
\hline \multirow[t]{2}{*}{3} & High $(>81.67)$ & 18 & 18.00 \\
\hline & Total & 100 & 100.00 \\
\hline \multicolumn{4}{|c|}{ Panchmahal district $($ Mean $=54.72, \mathrm{SD}=15.94)$} \\
\hline 1 & Low $(<38.78)$ & 21 & 21.00 \\
\hline 2 & Medium (38.78 to 70.66$)$ & 58 & 58.00 \\
\hline \multirow[t]{2}{*}{3} & High $(>70.66)$ & 21 & 21.00 \\
\hline & Total & 100 & 100.00 \\
\hline \multicolumn{4}{|c|}{ Overall $($ Mean $=59.91, \mathrm{SD}=17.03)$} \\
\hline 1 & Low $(<42.88)$ & 41 & 20.50 \\
\hline 2 & Medium (42.89 to 76.94$)$ & 134 & 67.00 \\
\hline \multirow[t]{2}{*}{3} & High (> 76.94) & 25 & 12.50 \\
\hline & Total & 200 & 100.00 \\
\hline
\end{tabular}

$\chi^{2}=1.05 \mathrm{NS}$

Table.2 Component-wise adoption level of improved animal husbandry practices by respondents in villages of Kheda and Panchamahal districts

\begin{tabular}{|c|c|c|c|c|c|}
\hline $\begin{array}{l}\text { Sr. } \\
\text { No. }\end{array}$ & Practices & $\begin{array}{c}\text { Kheda } \\
(\mathrm{N}=100)\end{array}$ & $\begin{array}{c}\text { Panchmahal } \\
(\mathrm{N}=100)\end{array}$ & $\begin{array}{c}\text { Overall } \\
(\mathrm{N}=200)\end{array}$ & Rank \\
\hline 1 & Calf management & 62.00 & 59.40 & 60.70 & IV \\
\hline 2 & Feeding management & 77.00 & 62.80 & 69.90 & III \\
\hline 3 & Milking management & 37.60 & 35.40 & 36.50 & $\mathrm{~V}$ \\
\hline 4 & Health management & 81.33 & 63.17 & 72.25 & II \\
\hline 5 & Reproductive management & 81.40 & 65.20 & 73.30 & I \\
\hline 6 & General management & 37.33 & 31.00 & 34.17 & VI \\
\hline & Overall & 62.78 & 52.83 & 57.80 & \\
\hline
\end{tabular}


Table.3 Correlation coefficients between respondents' profile and adoption level of improved animal husbandry practices

\begin{tabular}{|c|l|c|c|}
\hline \multirow{2}{*}{$\begin{array}{c}\text { Sr. } \\
\text { No. }\end{array}$} & \multicolumn{1}{|c|}{ Profile } & \multicolumn{2}{|c|}{ Correlation coefficients ('r' value) } \\
\cline { 2 - 4 } & & -0.161 & Panchmahal \\
\hline 1 & Age & $0.461^{* *}$ & -0.113 \\
\hline 2 & Education & 0.160 & 0.010 \\
\hline 3 & Caste & $-0.265^{* *}$ & -0.107 \\
\hline 4 & Family size & $-0.348^{* *}$ & -0.138 \\
\hline 5 & Experience & $0.198^{*}$ & -0.033 \\
\hline 6 & Social participation & $0.290^{* *}$ & 0.137 \\
\hline 7 & Land holding & $0.347^{* *}$ & 0.152 \\
\hline 8 & Annual income & $0.321^{* *}$ & $0.201^{*}$ \\
\hline 9 & Herd size & -0.019 & $0.255^{*}$ \\
\hline 10 & Economic motivation & 0.182 & 0.157 \\
\hline 11 & Risk orientation & -0.065 & $0.209^{*}$ \\
\hline 12 & Scientific orientation & 0.164 & $0.210^{*}$ \\
\hline 13 & Achievement motivation & $-0.216^{*}$ & 0.120 \\
\hline 14 & Attitude towards dairy farming & $0.235^{*}$ & -0.051 \\
\hline 15 & Mass media exposure & -0.062 & 0.184 \\
\hline 16 & Extension contact & & $0.241^{*}$ \\
\hline
\end{tabular}

Table.4 Stepwise regression analysis of respondent's profile and adoption of improved animal husbandry practices in Kheda and Panchmahal districts

\begin{tabular}{|c|c|c|c|c|c|}
\hline \multirow[t]{2}{*}{ Variables } & \multicolumn{2}{|c|}{$\begin{array}{l}\text { Unstandardized } \\
\text { Coefficients }\end{array}$} & \multirow{2}{*}{$\begin{array}{l}\text { Standardized } \\
\text { Coefficients } \\
\text { Beta }\end{array}$} & \multirow{2}{*}{$\begin{array}{c}\text { 't' } \\
\text { value }\end{array}$} & \multirow[t]{2}{*}{ Sig. } \\
\hline & $\mathrm{B}$ & Std. Error & & & \\
\hline \multicolumn{6}{|l|}{ Kheda district $\left(\mathrm{R}^{2}=38.20 \%\right)$} \\
\hline (Constant) & 42.704 & 5.902 & -- & 7.236 & 0.000 \\
\hline Education & $5.029 * *$ & 1.349 & 0.320 & 3.728 & 0.000 \\
\hline Experience in dairy farming & $-0.380 * *$ & 0.119 & -0.265 & -3.189 & 0.002 \\
\hline Herd size & $0.396 * *$ & 0.129 & 0.250 & 3.067 & 0.003 \\
\hline Land holding & $4.809 *$ & 1.890 & 0.212 & 2.545 & 0.013 \\
\hline \multicolumn{6}{|c|}{ Panchmahal district $\left(\mathrm{R}^{2}=10.80 \%\right)$} \\
\hline (Constant) & 44.758 & 3.419 & -- & 13.089 & 0.000 \\
\hline Herd Size & $0.595^{*}$ & 0.255 & 0.226 & 2.330 & 0.022 \\
\hline Extension contact & $3.819^{*}$ & 1.762 & 0.210 & 2.168 & 0.033 \\
\hline
\end{tabular}

${ }^{*} \mathrm{p}<0.05, * * \mathrm{p}<0.01$

The results are in agreement with Arora et al., (2006) regarding level of education, Shyam Singh et al., (2013) regarding land holding, social participation and family size, Durgga
(2009) regarding annual income and Khokhar (2008) regarding mass media exposure and herd size. However, the contradictory findings regarding attitude towards dairy farming and 
experience in dairy farming have been reported by Sharma and Singh (2008) and Gamit et al., (2015), respectively.

Among the profile of dairy farmers of Panchmahal district annual income, herd size, risk orientation, scientific orientation and extension contact had positive and significant $(p<0.05)$ association with adoption of improved animal husbandry practices. The present results are in agreement with findings of Durgga (2009) regarding annual income, Khokhar (2008) regarding herd size, Rizwan et al., (2015) regarding risk orientation and Gour (2002) regarding scientific orientation and extension contact.

The stepwise regression analysis was carried out taking adoption of improved animal husbandry practices as a dependent variable and 16 socio-personal profile characters of respondents as independent variables (Table 4). Out of sixteen characters, the amount of variation in adoption about animal husbandry practices of farmers in Kheda district was jointly contributed by independent variables to the extent of $38.20 \%$, where education, experience in dairy farming, herd size and land holding contributed significantly. In Panchmahal district, the independent variables contributed to the variation in adoption level to the extent of $10.80 \%$, where herd size and extension contacts contributed significantly. These results supported the findings of earlier researchers, wherein significant regression of education (Durga 2009), land holding (Shyam Singh et al., 2013) and extension contact (Gour 2002) on adoption was observed. However, Letha Devi et al., (2014) reported non-significant contribution of herd size.

From the present study, it can be concluded that still farmers of Panchmahal district were not adopting $45.00 \%$ of improved animal husbandry practices, while the corresponding value of non-adoption for Kheda district was $35.00 \%$. Thus, there is a need to make the farmers of Kheda and Panchmahal districts aware about importance of improved animal husbandry management practices through extension education programme and make available necessary essential veterinary services and other input facilities at their door step to improve their animals genetic makeup, health and productivity, and thereby improve their socio-economic condition and living standard.

\section{References}

Anonymous (2014). Annual Report 2013-14, Department of Animal Husbandry, Dairying and Fisheries, Government of India, New Delhi.

Arora AS, Avadesh Kumar, Bardhan D and Dabas YPS. 2006. Socio-economic and communication variables associated with level of knowledge and degree of adoption of improved dairy husbandry practices in US Nagar district of Uttaranchal. Indian Journal of Dairy Science 59(5): 337-343.

Chander M, Dutt T, Ravikumar R and Subrahmanyeswari B. 2010. Livestock technology transfer service in India: A review. Indian Journal of Animal Sciences 80: 1115-1125.

Durgga RV. 2009. Crisis management practices adopted in dairy farming by the farmers of Anand district of Gujarat state. Ph.D. Thesis, Anand Agricultural University, Anand, India.

Gamit MP, Durgga RV, Bhabhor IN, Tyagi KK and Rathod AD. 2015. Entrepreneurial behaviour of dairy farmers in Surat district of South Gujarat. International Journal of Advances in Multidisciplinary Research 2(8): 50-56.

Gour AK. 2002. Factors influencing adoption of some improved animal husbandry 
practices of dairying in Anand and Vadodara districts of Gujarat State. Ph.D. Thesis, Gujarat Agril University, Sardarkrushinagar, India.

Hamdani SA. 2008. Adoption pattern of improved dairy farming practices in Jammu district. MVSc Thesis, Sher-eKashmir University of Agricultural Sciences and Technology, Jammu, $\mathrm{J} \& \mathrm{~K}$, India.

Khokhar SR. 2008. A study on adoption of dairy innovations by dairy farm women in Anand district. MSc (Agri) Thesis, Anand Agricultural University, Anand, India.

Letha Devi G, Khandekar P and Chandrappa T. 2014. Management efficiency of dairy entrepreneurs: An analysis. Indian Research Journal of Extension Education 14(1): 1-4.

Prajapati JV. 2011. Adoption of no-cost and low-cost technologies of animal husbandry by tribal dairy farm women. MVSc Thesis, Anand Agricultural University, Anand, India.

Rizwan J, Shafkat A, Mohd Younas B, Pranav Kumar and Bhadwal M. 2015. Adoption of improved animal husbandry practices by Gujjars of Jammu and Kashmir. Indian Journal of Dairy Science 68(3): 287-292.

Sharma K and Singh SP. 2008. Dairy farmer's knowledge about buffalo feeding practices. Haryana Veterinarian 47: 6871.

Shyam Singh A, Singh K and Imtiwati 2013. Adoption of improved dairy husbandry practices by dairy farmers in hill region of Manipur, India. Asian Journal of Dairy \& Food Research 32(4): 283-289. TOI (2016). Times of India, Report, 23.07.2016.

\section{How to cite this article:}

Divekar, B.S. and Trivedi, M.M. 2017. Comparative Adoption Level of Improved Animal Husbandry Practices by Dairy Farmers of Kheda and Panchmahal Districts of Middle Gujarat, India. Int.J.Curr.Microbiol.App.Sci. 6(11): 3018-3023. doi: https://doi.org/10.20546/ijcmas.2017.611.353 